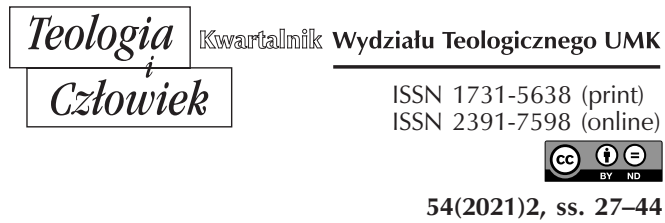

KS. DARIUSZ LIPIEC

KATOLICKI UNIWERSYTET LUBELSKI JANA PAWŁA II W LUBLINIE

\title{
FORMACJA PREZBITERÓW DO DUSZPASTERSTWA OSÓB Z NIEPEKNĄ SPRAWNOŚCIĄ
}

DOI: http://dx.doi.org/10.12775/TiCz.2021.009

Streszczenie. Duszpasterstwo osób z niepełną sprawnością to forma działalności Kościoła, urzeczywistniającą posługę zbawczą Kościoła przez głoszenie takim ludziom słowa Bożego, działalność liturgiczną, posługę pasterską i świadectwo życia chrześcijańskiego. Specyfika niepełnosprawności i życia ludzi obarczonych nią wymaga odpowiedniego przygotowania prezbiterów do pracy z nimi. Formacja ludzka polega w tym przypadku na kształtowaniu cech charakteru potrzebnych do współpracy z ludźmi z niepełną sprawnością. Z kolei formacja duchowa zmierza do pogłębienia miłości pasterskiej na wzór Jezusa Chrystusa Dobrego Pasterza oraz postawy służebnej wobec takich osób. Celem formacji intelektualnej jest przekazanie potrzebnej wiedzy dotyczącej niepełnosprawności i ludzi, którzy zostali nią dotknięci, natomiast formacja pastoralna zmierza do pogłębiania odpowiednich postaw nabywania umiejętności duszpasterskich. Formacja prezbiterów do duszpasterstwa osób z niepełną sprawnością powinna mieć charakter całościowy i integralny.

Słowa kluczowe: formacja prezbiterów; formacja kapłańska; niepełnosprawność; niepełna sprawność; osoba z niepełną sprawnością; osoba z niepełnosprawnością; duszpasterstwo niepełnosprawnych.

Abstract. Formation of presbyters for the pastoral care of people with disabilities. Pastoral care of people with disabilities is a form of ecclesial activity which 
realizes the salvific mission of the Church through proclaiming God's Word to people with disabilities, through the liturgical service, through pastoral ministry and through the testimony of the Christian life. The specific nature of disability and of the life of a person with disability requires certain preparation of religious scholars who are to work with them. Human formation consists in the formation of the features of character which are necessary for the work with people with disabilities. The spiritual formation aims at deepening pastoral love following the pattern of Jesus Christ the Good Shepherd as well as the attitude of service for such people. The aim of intellectual formation is to provide necessary knowledge which concerns disabilities and the people who suffer from disabilities, while pastoral formation aims at deepening certain attitudes of pastoral care skills acquisition. The formation of presbyters for the pastoral care of people with disabilities should be comprehensive and integral.

Keywords: formation of presbyters; priestly formation; disability; partial disability; pastoral care of people with disabilities.

We wspólnocie Kościoła znajduje się wiele osób doświadczających w różnoraki sposób niepełnej sprawności, które się z nią urodziły lub nabyły ją w trakcie życia. Są osoby mające ograniczenia w funkcjonowaniu ruchowym, ograniczenia sensoryczne, upośledzające wzrok lub słuch oraz intelektualne. Ograniczenia te mają negatywny wpływ na funkcjonowanie tych osób w życiu społecznym, kulturalnym i religijnym. W Kościele osoby z niepełną sprawnością objęte są duszpasterstwem. Jest ono rozumiane jako

forma działalności Kościoła [...] urzeczywistniająca wobec nich zbawcze dzieło Jezusa Chrystusa przez głoszenie słowa Bożego, liturgię, posługę pasterską i świadectwo życia chrześcijańskiego, z uwzględnieniem specyfiki funkcjonowania oraz środowiska ich życia; pośrednio obejmuje także osoby opiekujące się lub pracujące $\mathrm{z}$ niepełnosprawnymi ${ }^{1}$.

Specyfika środowiska życia oraz potrzeb wynikających z ograniczeń $\mathrm{w}$ funkcjonowaniu tych osób sprawiają, że posługa pastoralna wobec nich wyraża się w duszpasterstwie zwyczajnym i nadzwyczajnym. W zdecydowanej większości osoby obarczone niepełnosprawnością żyją w środo-

${ }^{1}$ J. Michalewski, S. Regmunt, Niepetnosprawnych duszpasterstwo, w: Encyklopedia katolicka, t. 13, kol. 1159. 
wisku rodzinnym i parafialnym, Dzięki temu objęte są one duszpasterstwem zwyczajnym, zmierzającym do ich pełnego upodmiotowienia we wspólnocie Kościoła. Wymaga to jednak dostosowania różnych dziedzin życia religijnego do specyfiki i potrzeb osób z niepełną sprawnością. Nie wszystkie jednak takie osoby mogą w pełni korzystać z duszpasterstwa zwyczajnego. Wynika to zarówno ze stopnia niepełnosprawności i jego skutków, jak i ze specyfiki duszpasterstwa zwyczajnego, kierowanego do jak najszerszego grona adresatów. Wówczas do tych osób kieruje się formy duszpasterstwa nadzwyczajnego, mającego być inspiracją i uzupełnieniem dla duszpasterstwa zwyczajnego ${ }^{2}$.

Duszpasterstwo osób z niepełną sprawnością wymaga dostosowania form i metod pracy do ich potrzeb i możliwości, a także przystosowania miejsc posługi pastoralnej i urządzeń w nich się znajdujących. Potrzebne jest także przygotowanie wspólnot wierzących do czynnej obecności takich osób w celu umożliwienia im korzystania ze wszystkich środków uświęcenia, jakimi dysponuje Kościół. Jako podstawowa konieczność jawi się formacja prezbiterów do pracy z takimi osobami, zarówno w duszpasterstwie zwyczajnym, jak i nadzwyczajnym ${ }^{3}$. Powinna to być formacja integralna i całościowa, obejmująca wszystkie jej wymiary: ludzki, duchowy, intelektualny i pastoralny ${ }^{4}$.

\section{FORMACJA LUDZKA}

Formacja ludzka określana jest mianem fundamentu formacji kapłańskiej.

Bez odpowiedniej formacji ludzkiej cała formacja kapłańska byłaby pozbawiona swego niezbędnego fundamentu. [...] Formacja ludzka kapłana okazuje się szczególnie ważna ze względu na tych, do których skierowana

2 Por. R. Kamiński, Duszpasterstwo nadzwyczajne, w: Teologia pastoralna, t. 2, red. R. Kamiński, Lublin 2002, s. 309-312.

${ }^{3}$ Por. D. Lipiec, Formacja pastoralna młodych prezbiterów w diecezjach $w$ Polsce. Studium teologicznopastoralne, Lublin 2020, s. 203-204.

4 Por. R. Kamiński, Formacja pastoralna, w: Encyklopedia katolicka, t. 5, kol. 391-392. 
jest jego misja. Właśnie po to, żeby jego posługa była po ludzku jak najbardziej wiarygodna i łatwa do przyjęcia, kapłan winien kształtować swą osobowość w taki sposób, by stawać się dla innych pomostem, a nie przeszkodą $\mathrm{w}$ ich spotkaniu z Jezusem Chrystusem Odkupicielem człowieka. Ważne jest, by kapłan [...] umiał poznawać do głębi wnętrze człowieka, odkrywać trudności i problemy, ułatwiać spotkanie i dialog, zdobywać zaufanie i nawiązywać współpracę, wyrażać spokojne i zrównoważone sądy.

Osoby z niepełną sprawnością są szczególnymi adresatami posługi zbawczej Kościoła. Wpływ uszkodzenia ciała lub niedomogów sfery intelektualnej na ich życie jest wieloraki. Jako zasadniczy można zauważyć wpływ na ich tożsamość, postrzeganie siebie i swego miejsca w społeczności ludzkiej i kościelnej. Osoby takie nierzadko postrzegają siebie - poprzez swoją odmienność - jako gorszych od innych ${ }^{6}$. W ten sposób stają się one „ubogimi” w Bożej ekonomii zbawienia i adresatami szczególnej troski Kościoła posłanego, aby nieść ubogim Dobrą Nowinę (por. Łk 4,18).

Dokument papieski zwraca uwagę także na aspekt społeczny posługi kapłańskiej, przez który formacja ludzka prezbiterów jest uznawana za fundament przygotowania do święceń i formacji stałej.

Szczególnie ważna jest zdolność do utrzymywania więzi z innymi, cecha naprawdę fundamentalna u kogoś, kto jest powołany, by ponosić odpowiedzialność za wspólnotę i być „człowiekiem jedności”. Dlatego kapłan nie może być arogancki ani kłótliwy, lecz uprzejmy, gościnny, szczery w słowach i intencjach, roztropny i dyskretny, wielkoduszny i gotowy do służby, zdolny utrzymywać otwarte i braterskie kontakty z innymi i nawiązywać je ze wszystkimi, zawsze gotów zrozumieć, przebaczyć i pocieszyć [...]. Ludzie współcześni, często skazani na życie w tłumie, a jednocześnie na samotność [...], stają się coraz bardziej wrażliwi na wartość wspólnoty. Jest ona dziś jednym z najbardziej wymownych znaków i jedną z najbardziej skutecznych metod głoszenia ewangelicznego orędzia ${ }^{7}$.

${ }^{5}$ Jan Paweł II, Posynodalna adhortacja apostolska Pastores dabo vobis, nr 43.

${ }^{6}$ Por. T. Majewski, Poradnik metodyczny dla nauczycieli pracujacych $z$ dziećmi uszkodzonym wzrokiem w systemie integracyjnym, Warszawa 1997, s. 40-48.

${ }^{7}$ Jan Paweł II, Posynodalna adhortacja apostolska Pastores dabo vobis, nr 43. 
Cechy duchownych wymienione w dokumencie nabierają szczególnego znaczenia $\mathrm{w}$ odniesieniu do osób z niepełną sprawnością. Współczesne przemiany kulturowe zmierzają w kierunku coraz dalej idącej ich integracji społecznej, która cechuje się zajmowaniem takich samych miejsc w społeczeństwie, jakie zajmują ludzie sprawni i podejmowanie takich samych ról, jakie pełnią $\mathrm{w}$ pełni sprawni. Oznacza to, że nie tylko osoby z niepełną sprawnością mają podejmować wysiłek rehabilitacyjny, ale także społeczeństwo powinno zrobić wszystko, co możliwe, aby funkcjonowały one w sposób jak najbardziej odpowiadający funkcjonowaniu ludzi sprawnych. W wielu wypadkach powoduje to znaczny wysiłek, obejmujący dostosowanie przestrzeni publicznej i jej urządzeń do możliwości osób z niepełną sprawnością, przede wszystkim jednak zmiany struktur i organizacji życia społecznego ${ }^{8}$. Duże znaczenie przywiązuje się w tym względzie do zaangażowania obywateli na rzecz osób z niepełnosprawnością, w pierwszej kolejności liderów życia społecznego, którzy w wysiłku integracyjnym ponoszą duży wysiłek. Dotyczy to także duchownych, należących do liderów życia społecznego w środowiskach lokalnych. Są oni także przewodnikami wspólnot eklezjalnych, na nich więc spoczywa znaczny wysiłek związany z integracją osób z niepełną sprawnością w parafiach, a przez nie z Kościołami partykularnymi i Kościołem powszechnym.

Osoby z niepełną sprawnością spotykają się z różnymi postawami duchownych i same wskazują na cechy, które powinni oni posiadać, aby móc właściwie i skutecznie pracować. Zwracają one uwagę, że duchowni powinni traktować ich jako ludzi normalnych, to znaczy tak, jak traktuje się ludzi sprawnych. Wskazują przy tym, że niektórzy duszpasterze traktują ich jak dzieci, co przekłada się na sposób prowadzenia rozmowy jak z dziećmi. Używają oni intonacji charakterystycznej dla dialogu z małymi dziećmi, używają słów stosowanych przez nie i często odwołują się do zdrobnień. Infantylny stosunek do osób z niepełną sprawnością może przejawiać się ponadto $\mathrm{w}$ dziwnych zachowaniach i sposobie pro-

8 Por. Franciszek, Orędzie na Międzynarodowy Dzień Niepełnosprawnych 2019 - https://www.ekai.pl/dokumenty/oredzie-papieza-franciszka-na-swiatowy-dzien-osobniepelnosprawnych-2019 (dostęp: 14.05.2021). 
wadzenia rozmów, co osoby te odbierają jako lekceważenie lub protekcjonalność ${ }^{9}$.

Doświadczając takiego traktowania, ludzie z niepełnosprawnością potrzebują od duchownych akceptacji, przyjacielskiego stosunku do siebie oraz serdeczności i życzliwości. Przez to pragną oni być traktowani jak inni ludzie. Oczekuje się ponadto, że takie postawy duszpasterzy będą stosowane częściej w odniesieniu do takich ludzi, ponieważ wskutek negatywnych doświadczeń są oni bardziej wrażliwi na złe traktowanie i właśnie od prezbiterów oczekują postaw humanistycznych, wynikających z miłości chrześcijańskiej.

Jako cechy szczególnie pożądane $\mathrm{w}$ pracy z osobami z niepełną sprawnością wskazuje się łatwość w nawiązywaniu kontaktów, bezpośredniość, przystępność, pogodne usposobienie, cierpliwość, wyrozumiałość i umiejętność jednakowego traktowania wszystkich ludzi. Są to cechy, których oczekuje się od wszystkich duszpasterzy, lecz w pracy z ludźmi z niepełnosprawnością mają one szczególne znaczenie. Umożliwiają one przyjmowanie postawy wyjścia do człowieka, nawiązania z nim kontaktu, zacieśniania więzi, prowadzenia dialogu zbawczego i w efekcie doprowadzenie do spotkania z Bogiem i rozwoju relacji z Nim. Takie cechy duchownych są pomocne $\mathrm{w}$ przekraczaniu własnych ograniczeń przez ludzi z niepełnosprawnością i szersze otwarcie się na współpracę $\mathrm{z}$ innymi i z Bogiem.

Równocześnie osoby z niepełną sprawnością wskazują na niepożądane cechy duchownych. Wynika to z negatywnych doświadczeń, jakie mieli w kontaktach z nimi. Do negatywnych cech należą: wyniosłość, sztywność, nieprzystępność brak życzliwości, ponure usposobienie i tym podobne. Zwraca się uwagę także na cechy, które utrudniają pracę duszpasterską: brak taktu i dyskrecji, niesłowność czy niepunktualność. Jako szczególnie dotkliwe zostało wskazane unikanie takich osób w miejscach publicznych i wstydzenie się kontaktów z nimi. Przejawia się to między innymi przez udawanie, że się ich nie widzi lub nie poznaje. Innym błędem duchownych jest dzielenie podopiecznych na lepszych i gorszych,

9 B.Z. Pawłowicz, Duszpasterstwo niewidomych, „Ateneum Kapłańskie” 103 (1984) z. 1, s. 98-99. 
faworyzowanie niektórych ze względu na określone cechy lub ich marginalizowanie $^{10}$.

Wymienione wyżej pozytywne cechy duchownych są konieczne do pracy z osobami z niepełną sprawnością zarówno $\mathrm{w}$ duszpasterstwie zwyczajnym, jak i nadzwyczajnym. Wskazuje się natomiast na takie cechy, które są konieczne do posługi w duszpasterstwie nadzwyczajnym, dedykowanym takim osobom. Na pierwszym miejscu akcentuje się osobiste zainteresowania posługą wśród nich. Zwraca się uwagę, że praca w takich środowiskach wiąże się z określonym charyzmatem, którego nie posiadają wszyscy prezbiterzy. Wymaga ona także umiejętności poświęcenia siebie oraz ofiarowywania innym własnych sił i czasu.

\section{FORMACJA DUCHOWA}

Omawiając problematykę formacji duchowej przyszłych duszpasterzy, Sobór Watykański II wskazuje, że

powinna być tak prowadzona, aby alumni nauczyli się żyć w zażyłej i nieustannej łączności z Ojcem przez Syna Jego Jezusa Chrystusa w Duchu Świętym. [...] Niech nauczą się szukać Chrystusa w [...] ludziach, do których są posyłani, szczególnie w biednych, maluczkich, chorych, grzesznikach i niewierzących ${ }^{11}$.

Papież Jan Paweł II wyjaśnił, że

formacja duchowa oznacza również szukanie Chrystusa $w$ ludziach. To prawda bowiem, że życie duchowe jest życiem wewnętrznym, zażyłością z Bogiem, życiem modlitwy i kontemplacji, ale właśnie spotkanie z Bogiem i z Jego miłością, miłością Ojca do wszystkich ludzi, domaga się bezwzględnie spotkania z bliźnim, stania się darem dla innych przez pokorną i bezinteresowną służbę... . [...] W tym sensie przygotowanie do kapłaństwa nie może pomijać solidnej formacji do praktykowania miłości, zwłaszcza miłości preferencyjnej do „ubogich”, w których wiara odkrywa obecność Jezusa $[\ldots]^{12}$.

\footnotetext{
10 Tamże, s. 99.

11 Sobór Watykański II, Dekret o formacji kańskiej Optatam totius, nr 8.

12 Jan Paweł II, Posynodalna adhortacja apostolska Pastores dabo vobis, nr 49.
} 
$\mathrm{Na}$ etapie formacji stałej, będącej przedłużeniem formacji seminaryjnej, następuje rozwój i pogłębienie kształtowania duchowego prezbiterów. Przejawia się ono między innymi umocnieniem świadomości służebnego charakteru posługi kapłańskiej. To co zostało zapoczątkowane podczas studiów przez ojców duchownych, a także podczas praktyk i ćwiczeń duszpasterskich, jest kontynuowane w pracy pastoralnej.

Po święceniach następuje konfrontacja wiedzy i wyobrażeń dotyczących działalności duszpasterskiej z jej realnym stanem. Niekiedy konfrontacja ta ma postać zderzenia, kiedy to wyobrażenia duchownych mijają się w znacznym stopniu od obrazu pracy w realnych warunkach, z konkretnymi ludźmi. Na doświadczenie wystawiona jest zwłaszcza świadomość służebności wobec wierzących, prezentujących coraz częściej postawy odległe od chrześcijańskich wzorców. Osoby z niepełną sprawnością przyjmują nierzadko postawę pretensjonalną, ich kontakty z duchownymi przybierają charakter życzeniowy. Mogą one także prezentować wiele różnorakich cech utrudniających postrzeganie ich jako ludzi, którym udzielanie wsparcia przychodzi z radością i daje satysfakcję w sposób naturalny. Formacja duchowa zmierza w tym względzie do pogłębienia postawy służebnej wobec osób z niepełną sprawnością mimo negatywnych doświadczeń i emocji, jakie mogą towarzyszyć pracy z nimi.

Innym celem formacji duchowej jest pogłębienie świadomości prezbiterów, że osoby obarczone niepełnosprawnością są tymi, których w nauczaniu Kościoła nazywa się ubogimi, maluczkimi, słabymi i tym podobnymi określeniami. Ubóstwo oznacza „W aspekcie negatywnym stan jednostki lub zbiorowości ludzkich określający kondycję materialną, społeczną, moralną, kulturową, duchową i polityczną w wymiarze niedoboru, wyrażający się głównie w niemożności zaspokojenia potrzeb indywidualnych i zbiorowych"13. Niepełnosprawność jest źródłem różnorakich ograniczeń w zaspokajaniu potrzeb ludzi nią dotkniętych. W rzeczywistości nie są zaspokajane wszystkie potrzeby, oczekiwania i marzenia takich osób, a przede wszystkim nie zawsze jest możliwe usunięcie samej niesprawności, co skutkuje negatywnymi skutkami w życiu sferze fizycznej, psychicznej i duchowej. Mimo wielorakiego wsparcia ze strony społeczeństwa skutki niepełnosprawności są odczuwalne przez

13 A. Pietrzak, Ubóstwo, w: Encyklopedia katolicka, t. 19, kol. 1268. 
całe życie człowieka. Obecność takich osób jest wyzwaniem także dla Kościoła, a zwłaszcza dla prezbiterów, będących przewodnikami wspólnot wierzących i formatorami chrześcijan ${ }^{14}$.

Dostrzeganie w ludziach $\mathrm{z}$ niepełnosprawnością maluczkich tego świata, którym należy przychodzić z pomocą, jest możliwe wtedy, gdy w procesie formacji prezbiterzy pogłębiają miłość pasterską na wzór Jezusa Chrystusa Dobrego Pasterza i Sługi. Zakorzeniona w miłości chrześcijańskiej, uzdalnia ich ona nie tylko do dostrzegania Go w ludziach z niepełną sprawnością, ale przyjmowanie postawy wyjścia ku nim, nawet kosztem ofiary z siebie, własnego czasu i posiadanych dóbr. Miłość pasterska umożliwia koncentrowanie się wyłącznie na dobru osoby, której przychodzi się z pomocą, samemu zaś wsparciu nadaje znamię bezinteresowności ${ }^{15}$.

Praktykowanie miłości pasterskiej w odniesieniu do osób z niepełną sprawnością nie ma nic wspólnego z okazywaniem im litości. Litość ma często charakter subiektywny, wynikający z wrażliwości poszczególnych osób. Ludzie bardziej wrażliwi na dobro i potrzeby innych są bardziej skłonni do okazywania wsparcia, niż będący mniej wrażliwymi. Wrażliwość z kolei może wynikać z indywidualnych predyspozycji i sposobu wychowania. Miłość pasterska wynika natomiast z miłości chrześcijańskiej, pozostawionej ludowi Bożemu przez Chrystusa. Ma ona charakter obiektywny, niezależny od indywidualnego nastawienia wobec innych. Ze względu na fakt, że miłość chrześcijańska ma charakter zobowiązujący została dana jako przykazanie - powinna być realizowana ze względu na Chrystusa, który oddał życie za wszystkich ludzi ${ }^{16}$.

Traktowanie ludzi ubogich z litością nie jest przez nich dobrze odbierane. Również osoby z niepełną sprawnością niechętnie wchodzą w relacje z ludźmi ją okazującymi. Postawa taka odbierana jest jako upokarzająca. Ludzie litujący się postrzegani są jako prezentujący swoją

${ }^{14}$ Franciszek, Orędzie na Międzynarodowy Dzień Osób Niepełnosprawnych 2020 - https://www.ekai.pl/dokumenty/oredzie-papieza-franciszka-z-okazjimiedzynarodowego-dnia-osob-niepelnosprawnych (14.05.2021).

15 Por. A. Cencini, Drzewo życia. Ku modelowi formacji początkowej i permanentnej, Kraków 2005, s. 104-110.

16 Por. J. Wątroba, Permanentna formacja duchowa kapłanów w świetle soborowych i posoborowych dokumentów Urzędu Nauczycielskiego Kościoła (1963-1994), Częstochowa 1999, s. 138-142. 
„wyższość”, nawet jeśli nie mają takiej intencji, a ich działanie wynika $\mathrm{z}$ bezinteresowności. Przyjmowanie pomocy udzielanej z litości bywa doświadczane jako poniżające. $\mathrm{Z}$ tego powodu duchowni nie mogą się nią motywować ani jej okazywać.

Duchowni nie powinni czuć się przymuszeni do duszpasterstwa osób z niepełnosprawnością. W procesie formacji początkowej jak i stałej mają oni mieć świadomość posłania do ubogich. Uczestnicząc w formacji duchowej, mają oni za zadanie pogłębiać tę świadomość i przełamywać w sobie obawy i lęki towarzyszące pracy z takimi osobami. Dotyczy to wszystkich prezbiterów posługujących w ramach duszpasterstwa zwyczajnego. W przypadku rekrutacji księży do duszpasterstwa nadzwyczajnego, należy jednak brać pod uwagę ich wolę i predyspozycje. Duszpasterstwo nadzwyczajne wymaga bowiem duchownych mających odpowiednie cechy. Ich wolna wola odgrywa w tym względzie znaczącą rolę. Nie powinni to być ludzie przymuszeni, ponieważ mogą mieć trudności z pełnym zaangażowaniem się $\mathrm{w}$ pracę pastoralną ${ }^{17}$.

Z miłości pasterskiej, do której kształtowania się zobowiązani są wszyscy prezbiterzy, wynika potrzeba udzielania daru z siebie osobom z niepełną sprawnością. Osoby takie oczekują w pierwszej kolejności okazania im „serca”, co należy rozumieć jako uwagę i czas. Wówczas mają one poczucie, że są ważni dla swych pasterzy, a tym samym dla Kościoła. Oczekują one także, że duchowni będą się dobrze czuli w ich towarzystwie. Jako wyzwanie jawi się pogłębianie umiejętności odpoczywania $\mathrm{w}$ obecności osób z niepełnosprawnością. Jako naganne odbierają one natomiast takie zachowania duchownych, jak: lekceważenie ich, małe zaangażowanie $\mathrm{w}$ pracę pastoralną, okazywanie, że pracę te wykonują z przymusu i tym podobne ${ }^{18}$. Zachowania takie muszą być przedmiotem pracy duchowej, aby zostały przezwyciężone i przekształcone w postawy pozytywne, nacechowane szacunkiem. Ludzie ci odznaczają się bowiem szczególną wrażliwość na traktowanie przez innych.

17 Por. T. Paszkowska, Formacja eklezjalna - permanentny proces odnowy osobowej, Kraków 2019, s. 41-43.

18 B.Z. Pawłowicz, Duszpasterstwo niewidomych, s. 99-101. 


\section{FORMACJA INTELEKTUALNA}

Formacja intelektualna stanowi część formacji integralnej prezbitera; co więcej, stanowi niezbędną pomoc $\mathrm{w}$ posłudze pasterskiej i wpływa na formacje ludzką i duchową, które są przez nią wspomagane. Oznacza to, że pogłębienie wszystkich zdolności osoby, łącznie z umysłową, poprzez szeroki zakres nabytej wiedzy, przyczynia się do rozwoju prezbitera, sługi i świadka Słowa w Kościele i świecie. Formacja intelektualna rozumiana nie tylko jako przestrzeń wiedzy czy też narzędzie zdobywania większej ilości informacji z poszczególnych dyscyplin, pomaga prezbiterom wsłuchiwać się uważnie w słowo Boże oraz głos wspólnoty kościelnej, aby nauczyli się rozeznawać znaki czasów ${ }^{19}$.

W Dyrektorium o posłudze i życiu prezbiterów Kongregacja do Spraw Duchowieństwa precyzuje, że

$\mathrm{w}$ formacji intelektualnej szczególny nacisk powinien być położony na tematy, które mają dzisiaj duże znaczenie w dyskusjach kulturowych i praktyce duszpasterskiej, jak na przykład kwestie dotyczące etyki społecznej, bioetyki itd. Szczególną wagę należy poświęcić zagadnieniom, które wynikają z postępu naukowego, zwłaszcza wpływającego na mentalność i życie ludzi współczesnych. Prezbiter nie powinien uchylać się od właściwego uzupełniania wiedzy [...]. Powinien orientować się w postępie nauki i bez wahania podejmować konsultacje z ekspertami odznaczającymi się przygotowaniem i pewną doktrynąa ${ }^{20}$.

Wiedza dotycząca niepełnosprawności i ludzi nią dotkniętych powinna być przekazywana na wszystkich etapach formacji kapłańskiej. Podczas formacji seminaryjnej przyszli duchowni powinni zostać zapoznani z istotą niepełnej sprawności i jej wpływem na życie osobiste i społeczne człowieka. Konieczne jest, aby alumni otrzymali informacje dotyczące rodzajów niepełnosprawności oraz ich genezy; powinni oni znać specyfikę niepełnosprawności ruchowej, słuchu, widzenia i intelektualnej. Potrzeba, aby poznali oni różnice w sytuacji egzystencjalnej człowieka między jego

19 Kongregacja do Spraw Duchowieństwa, Dar powołania do kapłaństwa. Ratio fundamentalis institutionis sacerdotalis, nr 117.

${ }^{20}$ Kongregacja do Spraw Duchowieństwa, Dyrektorium o postudze i życiu prezbiterów, nr 95. 
urodzeniem się z niepełną sprawnością, a jej nabyciem $\mathrm{w}$ ciągu życia, a także by znali stopnie niepełnosprawności. Taka wiedza pomaga zrozumieć stan fizyczny, psychiczny i duchowy takich osób.

Poznanie niepełnosprawności prowadzi do zrozumienia wpływu, jaki ma na sferę poznawczą człowieka, a w związku z tym na możliwości jego wychowania i kształcenia. Znajomość wpływu na poznanie świata przez człowieka z niepełną sprawnością pozwala następnie zrozumieć jego możliwości komunikacyjne. Chodzi tu o komunikację bezpośrednią, czyli chodzenie, korzystanie ze środków komunikacji, takich jak samochód, rower, motocykl oraz o korzystanie z komunikacji masowej: pociągów, autobusów, samolotów i innych. Ograniczenia w sferze poznawczej mają również negatywny wpływ na dostęp do kształcenia i korzystanie z dóbr kultury. Skutkuje to mniejszymi szansami na rozwój osobisty, w tym intelektualny i emocjonalny, oraz na poszerzanie horyzontów kulturalnych.

Studiujący w seminarium powinni zapoznać się z wpływem niepełnosprawności na życie społeczne człowieka. Jako istotne należy uznać zrozumienie jej oddziaływania na życie małżeńskie i rodzinne oraz funkcjonowanie wspólnot małżeńsko-rodzinnych $\mathrm{z}$ małżonkiem-rodzicem $\mathrm{z}$ niepełną sprawnością oraz rodzin $\mathrm{z}$ takimi dziećmi ${ }^{21}$. Równie ważne jest poznanie skutków niepełnosprawności w funkcjonowaniu osób nią obarczonych w społeczeństwie, w tym możliwości zawodowych i sposobów spędzania czasu wolnego.

Dla przyszłych duchownych ważne jest poznanie wpływu niepełnosprawności na religijność człowieka. Chodzi tu w pierwszej kolejności o możliwość nawiązywania i budowania osobistych relacji z Bogiem, a następnie o formy uczestnictwa we wspólnocie Kościoła i korzystania $\mathrm{z}$ dóbr duchowych, jakimi on dysponuje ${ }^{22}$.

Ze względu na przyszłą pracę duszpasterską alumni powinni zostać zapoznani z rehabilitacją osób z niepełną sprawnością. Dotyczy to możliwości specyficznych dla poszczególnych rodzajów i stopni niepełnosprawności, a także systemu rehabilitacji w Polsce. Jako ważne należy

${ }^{21}$ Por. D. Lipiec, Duszpasterstwo rodzin osób niepetnosprawnych, „Roczniki Pastoralno-Katechetyczne” 3 (2011), s. 366-370.

22 Por. tenże, Duszpasterstwo niepelnosprawnych $w$ diecezji, „Roczniki Pastoralno-Katechetyczne" 4 (2012), s. 66-70. 
uznać poznanie szkolnictwa osób z niepełną sprawnością i ich wychowania $\mathrm{w}$ systemie integracyjnym i specjalnym.

Wiedza dotycząca niepełnosprawności i ludzi nią dotkniętych należy do różnych dyscyplin naukowych. $\mathrm{Z}$ tego powodu w ramach studiów seminaryjnych potrzebne jest jej przekazywanie w ramach studium psychologii, pedagogiki, socjologii, nauk o rodzinie, teologii pastoralnej, katechetyki, liturgiki i innych. Kompendium informacji o osobach $\mathrm{z}$ niepełną sprawnością jest $\mathrm{w}$ pierwszej kolejności konieczne do pracy w ramach duszpasterstwa zwyczajnego, realizowanego głównie na szczeblu parafialnym.

Istnieje potrzeba, aby problematyka niepełnosprawności była obecna $\mathrm{w}$ formacji stałej prezbiterów. Zgodnie z tym, co podaje Kongregacja do Spraw Duchowieństwa w wyżej wspomnianych dokumentach, dokonują się zmiany w otoczeniu społecznym, w którym Kościół prowadzi duszpasterstwo. Zmiany te dotyczą także osób z niepełną sprawnością. $\mathrm{W}$ realiach polskich zmiany te dotyczą już samego pojmowania niepełnosprawności, co wynika z ustaleń Światowej Organizacji Zdrowia oraz Unii Europejskiej. Skutkiem tego jest zmiana postrzegania osób nią obarczonych w przestrzeni publicznej. Zmierza się do ich pełnej integracji, a co za tym idzie, do coraz większego obciążania ludzi sprawnych kosztami społecznymi i materialnymi tego procesu.

Proces ten obejmuje wprowadzanie zmian w prawodawstwie państwowym, którego wymogi respektuje także Kościół. W ramach formacji stałej prezbiterów potrzebne jest ich poznawanie. Skutkują one bowiem koniecznością dostosowania różnorakich urządzeń kościelnych do potrzeb osób z niepełną sprawnością. Skutkiem zmian jest również potrzeba dostosowania form i metod duszpasterskich do uwarunkowań życia takich osób. Niekiedy trzeba je modyfikować lub wprowadzać nowe, aby ci ludzie zostali objęci skuteczną działalnością pastoralną.

Odrębnym zagadnieniem jest formacja intelektualna prezbiterów do pracy z osobami z niepełną sprawnością w ośrodkach, szkołach lub oddziałach im dedykowanych. Duchowni pracujący jako katecheci w ośrodkach szkolno-wychowawczych dla dzieci i młodzieży oraz w szkołach integracyjnych i szkołach z oddziałami integracyjnymi powinni legitymować się odpowiednim przygotowaniem psychologicznym, pedagogicznym i katechetycznym, czego wymaga prawo państwowe. Konieczne jest także 
specjalistyczne przygotowanie duchownych do pracy w ośrodkach dla dorosłych, zarówno rehabilitacyjnych, jak w domach opieki. Podobnie potrzebne jest takie przygotowanie do posługi w ramach duszpasterstwa nadzwyczajnego, realizowanego na szczeblu diecezjalnym i ponaddiecezjalnym. Powinni oni posiadać specjalistyczną wiedzę na wyższym poziomie, niż ta potrzebna do duszpasterstwa zwyczajnego. Ci duchowni objęci są odrębnymi sposobami kształcenia.

\section{FORMACJA PASTORALNA}

Formacja pastoralna bywa nazywana także duszpasterską, jednak - jak podaje adhortacja apostolska Pastores dabo vobis -

formacja duszpasterska z pewnością nie może sprowadzać się do zwykłego przeszkolenia, którego celem jest poznawanie pewnych technik duszpasterskich. Program wychowawczy seminarium musi zainicjować autentyczny proces kształtowania wrażliwości pasterskiej, przygotować do świadomego i dojrzałego przyjęcia odpowiedzialności, wpajać wewnętrzny nawyk oceniania problemów, ustalania priorytetów i wyboru rozwiązań w świetle jednoznacznych nakazów wiary i zgodnie z teologicznymi wymogami samego duszpasterstwa ${ }^{23}$.

Tak rozumiana formacja pastoralna ma za cel ukształtowanie duchownych na wzór Jezusa Chrystusa Dobrego Pasterza, co oznacza, że ich posługa powinna mień charakter służebny wobec Mistrza, którego naśladują, Królestwa Bożego, do budowania którego się przyczyniają i do ludzi, do których są posyłani. Kongregacja do Spraw Duchowieństwa wskazuje na osoby, względem których taka postawa jest wymagana w pierwszej kolejności. „Szczególną uwagę powinno poświęcić się przygotowaniu [...] do specyficznego towarzyszenia duszpasterskiego dzieciom, młodzieży, chorym, ludziom w podeszłym wieku, osobom niepełnosprawnym, więźniom, oraz żyjącym w samotności lub biedzie [...]"24.

${ }^{23}$ Jan Paweł II, Posynodalna adhortacja apostolska Pastores dabo vobis, nr 58.

${ }^{24}$ Kongregacja do Spraw Duchowieństwa, Dar powołania do kapłaństwa. Ratio fundamentalis institutionis sacerdotalis, nr 124. 
Te i inne formy działalności pasterskiej przygotowują [...] kapłana do przeżywania swojej misji „zwierzchnika” wspólnoty jako „służby”, uczą go unikać przyjmowania postaw wyższości i takiego sprawowania władzy, które nie byłoby usprawiedliwione jedynie i w każdym przypadku miłością pasterska ${ }^{25}$.

Z nauczania Kościoła wynika, że podstawową umiejętnością, którą należy ukształtować $\mathrm{w}$ duchownych w odniesieniu do osób z niepełną sprawnością jest zdolność ich dostrzegania we wspólnocie wierzących. Duszpasterstwo zwyczajne adresowane jest do ogółu wiernych, którzy traktowani są w sposób jednolity. Ze względu na wolę dotarcia do jak największej ich liczby w stosunkowo niewielkim stopniu uwzględniana jest specyfika poszczególnych ich grup i osób. Ten rodzaj duszpasterstwa zmierza bowiem do zaspokojenia powszechnych potrzeb religijnych człowieka. W dużych wspólnotach wiernych, także w parafiach, znajdują się jednak osoby będące w szczególnych okolicznościach życia i mające specyficznie określone potrzeby religijne i oczekiwania względem duszpasterstwa ${ }^{26}$. Do takich osób należą ludzie z niepełną sprawnością. Oznacza to konieczność przechodzenia od duszpasterstwa masowego do grupowego i indywidualnego. Należy także zauważyć, że ludzie z niepełną sprawnością nie stanowią jednolitej grupy, ponieważ obarczeni są różnymi rodzajami niepełnosprawności, $\mathrm{w}$ różnorakim stopniu.

Wrażliwość na wierzących i ich sytuację egzystencjalną, którą powinien cechować się duszpasterz, w odniesieniu do ludzi z niepełną sprawnością wiąże się umiejętnością dostrzegania ich indywidualności. Oznacza to konieczność ich osobistego poznania i ich sytuacji życiowej. Wynikiem tego poznania jest znajomość genezy i stopnia niepełnosprawności, jaką są oni obciążeni. Przedmiotem troski pastoralnej jest także ich życie wspólnotowe, zwłaszcza w społeczności lokalnej. Z aktywnością społeczną łączy się zaangażowanie zawodowe, a co za tym idzie, także warunki materialne i bytowe. Celem formacji pastoralnej prezbiterów zwłaszcza formatio permanens - jest rozwój ich wrażliwości na potrzeby osób z niepełną sprawnością. Wrażliwość ta powinna odnosić się zarówno

${ }^{25}$ Jan Paweł II, Posynodalna adhortacja apostolska Pastores dabo vobis, nr 58.

${ }^{26}$ Por. K. Pawlina, Formacja do kapłaństwa w polskich seminariach duchownych, Warszawa 2008, s. 158-159. 
do potrzeb religijnych, jak i materialnych oraz psychicznych. Wszystkie one bowiem są przedmiotem pasterskiego zainteresowania Kościoła ${ }^{27}$.

Formacja pastoralna, jak wynika z nauczania Kościoła, zmierza do stałego wzmacniania woli dostrzegania i rozwiązywania problemów duszpasterskich. Obecność osób z niepełną sprawnością we wspólnocie Kościoła należy uznać jako wyzwanie dla działalności pastoralnej. Dlatego duchowni nie mogą unikać takich osób, powinni natomiast zmierzać do nawiązywania $\mathrm{z}$ nimi indywidualnych kontaktów i rozwijania relacji o charakterze duszpasterskim.

Koniecznym elementem formacji pastoralnej, szczególnie na jej etapie permanentnym, jest poznawanie i doskonalenie form i metod pracy z osobami z niepełnosprawnością. Wprowadzenie w duszpasterstwo takich osób, jakie odbywa się w czasie studiów seminaryjnych wymaga ciągłego rozwoju i doskonalenia. Badania naukowe nad niepełnosprawnością przynoszą wiele korzyści dla życia osób nią obarczonych. Koniczne jest zatem doskonalenie metod i technik pracy z nimi, aby w pełniejszy sposób zaspokajać ich potrzeby religijne, ułatwiać funkcjonowanie we wspólnocie Kościoła i osiągnięcie zbawienia ${ }^{28}$.

Odrębnym zagadnieniem jest przygotowanie duchownych do pracy w ramach duszpasterstwa nadzwyczajnego. Duszpasterstwo takie zarówno na szczeblu ponadparafialnym, jak i w ośrodkach dla osób z niepełnosprawnością wymaga umiejętności porównywalnych z umiejętnościami nauczycieli, terapeutów czy rehabilitantów. Duchowni nie muszą posiadać wszystkich takich umiejętności, powinni jednak nauczyć się wszystkich tych, które są potrzebne do skutecznego duszpasterzowania.

\section{ZAKOŃCZENIE}

Duszpasterstwo osób z niepełną sprawnością wymaga odpowiednio przygotowanych prezbiterów. Ich formacja powinna być całościowa i integralna, obejmująca wymiary: ludzki, duchowy, intelektualny i pastoralny.

27 Por. W. Wermter, Kapłan z powołania, Częstochowa 1998, s. 91-92.

${ }_{28}$ Por. S. Staśko, Działalność duszpasterstwa osób niepetnosprawnych ruchowo i Katolickiego Stowarzyszenia „Cyrenejczyk” w latach 1986-2016. Studium pastoralno-katechetyczne, Kraków 2018, s. 217-272. 
Problematyka niepełnosprawności wywiera specyficzny wpływ na każdy z tych wymiarów sprawiając, że duchowni mogą w pełniejszy sposób odpowiadać na potrzeby i oczekiwania osób dotkniętych nią, i w ten sposób skuteczniej realizować wobec nich posłannictwo zbawcze Kościoła. Formacja do pracy z osobami z niepełną sprawnością ma swój początek podczas studiów seminaryjnych i znajduje kontynuację $\mathrm{w}$ ramach formacji stałej. Celem takiej formacji jest przygotowanie ogółu duchownych do pracy $\mathrm{z}$ takimi osobami w ramach duszpasterstwa zwyczajnego, jak również wybranych prezbiterów do posługi w ramach duszpasterstwa nadzwyczajnego na płaszczyźnie ponadparafialnej i w ośrodkach dla osób z niepełną sprawnością.

\section{BIBLIOGRAFIA}

Cencini A., Drzewo życia. Ku modelowi formacji początkowej i permanentnej, Wydawnictwo Salwator, Kraków 2005.

Franciszek, Orędzie na Międzynarodowy Dzień Niepełnosprawnych 2019 - https:// www.ekai.pl/dokumenty/oredzie-papieza-franciszka-na-swiatowy-dzien-osobniepelnosprawnych-2019 (14.05.2021).

Franciszek, Orędzie na Międzynarodowy Dzień Osób Niepełnosprawnych 2020 - https:// www.ekai.pl/dokumenty/oredzie-papieza-franciszka-z-okazji-miedzynarodowegodnia-osob-niepelnosprawnych (14.05.2021).

Jan Paweł II, Posynodalna adhortacja apostolska Pastores dabo vobis, w: Adhortacje Ojca Świętego Jana Pawła II, t. 2, Wydawnictwo św. Stanisława B.M. i Wydawnictwo M, Kraków 1996, s. 409-540.

Kamiński R., Duszpasterstwo nadzwyczajne, w: Teologia pastoralna, t. 2, red. R. Kamiński, Atla 2, Lublin 2002, s. 309-312.

Kamiński R., Formacja pastoralna, w: Encyklopedia katolicka, t. 5, kol. 391-392.

Kongregacja do Spraw Duchowieństwa, Dyrektorium o posłudze i życiu prezbiterów (11.02.2013), Wydawnictwo Karmelitów Bosych, Kraków 2013.

Kongregacja do Spraw Duchowieństwa, Dar powołania kapłańskiego. Ratio Fundamentalis Institutionis Sacerdotalis (8.12.2016), Libreria Editrice Vativana, Watykan 2016.

Lipiec D., Duszpasterstwo rodzin osób niepełnosprawnych, „Roczniki Pastoralno-Katechetyczne" 3 (2011), s. 364-378.

Lipiec D., Duszpasterstwo niepetnosprawnych $w$ diecezji, „Roczniki Pastoralno-Katechetyczne" 4 (2012), s. 65-79.

Lipiec D., Formacja pastoralna młodych prezbiterów $w$ diecezjach $w$ Polsce. Studium teologicznopastoralne, Wydawnictwo KUL, Lublin 2020. 
Majewski T., Poradnik metodyczny dla nauczycieli pracujących z dziećmi uszkodzonym wzrokiem $w$ systemie integracyjnym, Ministerstwo Edukacji Narodowej, Warszawa 1997.

Michalewski J., Regmunt S., Niepetnosprawnych duszpasterstwo, w: Encyklopedia katolicka t. 13, kol. 1159-1161.

Paszkowska T., Formacja eklezjalna - permanentny proces odnowy osobowej, Wydawnictwo Alleluja, Kraków 2019.

Pawlina K., Formacja do kapłaństwa w polskich seminariach duchownych, Wydawnictwo Sióstr Loretanek, Warszawa 2008.

Pawłowicz B.Z., Duszpasterstwo niewidomych, „Ateneum Kapłańskie” 103 (1984) z. 1, s. 96-108.

Pietrzak A., Ubóstwo, w: Encyklopedia katolicka, t. 19, kol. 1268.

Sobór Watykański II, Dekret o formacji kańskiej Optatam totius (28.10.1965), w: Sobór Watykański II, Konstytucje, dekrety, deklaracje, Pallottinum, Poznań 2002, s. 288-301.

Staśko S., Działalność duszpasterstwa osób niepełnosprawnych ruchowo i Katolickiego Stowarzyszenia „Cyrenejczyk” w latach 1986-2016. Studium pastoralno-katechetyczne, UPJP II Wydawnictwo Naukowe, Kraków 2018.

Wątroba J., Permanentna formacja duchowa kapłanów w świetle soborowych i posoborowych dokumentów Urzędu Nauczycielskiego Kościoła (1963-1994), Kuria Metropolitalna i Tygodnik Katolicki „Niedziela”, Częstochowa 1999.

Wermter W., Kapłan z powołania, Wydawnictwo Misjonarzy Krwi Chrystusa POMOC, Częstochowa 1998. 